\title{
Introduction: Public Theology after Maidan
}

The history of the evangelical church under Soviet communism is the history of a marginal existence and a constant struggle for survival in a hostile context of persecution and state-endorsed atheism. Under such conditions, serious theological engagement with issues of common public concern seemed liked an unaffordable luxury for many Christians. The experience of living under an oppressive Marxist-Leninist ideology led to the idealization of marginality and withdrawal from the world as the most faithful mode of Christian existence. Theological reflection on public issues was regarded as unnecessary, because there seemed to be no hope for the transformation of society. The assumption was that all one could do was to live as a separated minority, attending to one's private devotion to God and living in a perpetual waiting mode for the "end times". Public theology was simply not on the agenda of most Christians living behind the Iron Curtain.

In the early 1990s, following the demise of the Soviet Union, a wave of missionary euphoria swept through the newly-liberated nations of the postCommunist bloc in Eastern Europe. Notwithstanding this initial enthusiasm, which led to a temporary revival of Christian faith, many of the churches in these nations are now in steep decline. The decline of Christianity, following the initial years of dynamic growth after the collapse of the USSR, has been partly attributed to the failure of post-Soviet theologians to develop a contextual public theology that would equip Christians to respond creatively and compassionately to the social, political, cultural, economic and spiritual realities of the region. Despite the long tradition of the association of Christian faith (or more precisely, Orthodox Christian faith) with political authority and national identity, post-Soviet Christians of all denominations had no tradition of thinking theologically or biblically about political events or social processes.

Throughout the 199os and the first decade of the 20oos, the notion of public theology, as a recognised and respected academic pursuit, was virtually nonexistent in the nations of the former Soviet Union. Even the term itself was not widely used or understood. The public participation of the church in the life of post-Soviet society was constrained not only by restrictive legislation and general public indifference to theology, but also by the social doctrines of Christians themselves, who had inherited the Soviet assumption that religion, 
where it was tolerated at all, was a strictly private matter. Little effort was made to understand how the gospel penetrates every sphere of life or how faith is not merely a private matter of personal piety, but extends to every area of life, including politics, society, academia, the arts and media.

In recent years, however, there are promising signs that public theology is finally beginning to emerge as a recognized and respected pursuit that deserves serious attention by theologians, philosophers and sociologists in the former Soviet Union. In the aftermath of the momentous events of the Ukrainian Revolution of Dignity and Freedom in 2013-14, a new generation of younger scholars has emerged to offer robust theological critiques of post-Soviet society. Thanks to the pioneering work of Christian public intellectuals, such as Mykhailo Cherenkov, Cyril Hovorun, Oleksandr Geychenko, Roman Soloviy, Orysya Bila, Viktoriya Lyubashchenko and others, there is a growing understanding of how theological and philosophical ideas are inextricably connected with socio-political developments in the post-Soviet space.

Given the prominence of Ukraine in the emergence of public theology as a recognised academic pursuit, it is no coincidence that most of the articles brought together in this special issue began as papers presented at an international theological conference, hosted by the Ukrainian Catholic University (UCU) in Lviv in Western Ukraine. This conference, which featured plenary speakers from Western and Eastern Europe, marked the latest stage in the consolidation of UCU as major regional hub of theological thinking about the public significance of Christian faith and a centre of knowledge that attracts not only academics, but also politicians, businesspeople and journalists. The theme of the conference was "The Church and Public: Love in Action".

This special issue of the International Journal of Public Theology brings together some of the most fruitful lines of enquiry currently being pursued by public theologians in Eastern Europe. The unifying theme of the various contributions consists in the authors' common conviction that theology still has something vital and urgent to contribute to the salient issues and challenges that arise out of the public sphere in the nations of the former Soviet Union. This conviction is apparent throughout the first article by Joshua T. Searle, entitled, 'Freedom, Compassion and Creativity'. Searle discusses the theological significance of the Revolution of Dignity in Ukraine in 2013-14 and considers how this momentous event has become a catalyst for the formulation and development of a new theological paradigm that takes the fundamental principles of freedom, compassion and creativity as its point of departure. The Revolution has created a blurring of the boundaries between the sacred 
and the secular, contends Searle, who concludes that a renewed focus on the Kingdom of God, rather than the national church, as the proper missional point of departure creates new opportunities for public theology in the former Soviet Union.

Roman Soloviy is also convinced of the important contribution that public theology could make towards the transformation of the post-Soviet church and the wider society. In his article entitled, 'The Challenges of Radical Hospitality for Evangelical Public Theology', Soloviy explores how the public engagement of Ukrainian Christians could be augmented by an engagement with hospitality, as formulated in the writings of Jacques Derrida and his interpreters. He commends recent attempts by post-Soviet theologians to embed the principles of pluralism and tolerance within theological discourse, but contends that these qualities must be supplemented by the virtue of hospitality in order to promote healthy dialogue both within the churches and between the churches and the wider society. The practice of hospitality requires that Christians be prepared to acknowledge the presence of God outside of the confines of ecclesial space. As Soloviy concludes, 'Christianity is not a separate island in the ocean of an antagonistic world; on the contrary, the world is a small island in the ocean of hospitable Christianity, perceived as the presence of the Kingdom of God'.

Heleen Zorgdrager's article, 'Churches, Dignity, Gender', takes the example of the Istanbul Convention as a test case to explore how the concept of gender became a focal point of discussion in Ukraine. The ratification of the Istanbul Convention, which aimed to combat violence against women, required that signatory states adopt appropriate legislation to protect women from domestic violence and to develop educational programs which address structural causes of gender-based violence. Taking a socio-political and a public-theological perspective, Zorgdrager examines how sections of Ukrainian society, including male-dominated Ukrainian parliamentary committees, NGOs and Christian churches, typically oppose the ratification of the Istanbul Convention by appealing to traditional values. Zorgdrager considers the politicization of family values and how the appeal to such values can be utilized by populist politicians to advance their nefarious ideological ambitions. The article makes a compelling case for the contribution that public theology makes towards the framing of cultural debates around issues of gender and sexuality. Zorgdrager concludes that public theology has an important role to play in the development of a gender-sensitive understanding of dignity. In order to fulfil this role, public theology should be open to hear and include the voices of ordinary women. 
Oleksandr Geychenko, in his article on 'The Church, Kingdom and Society in the Writings of Vasilii V. Ivanov (1846-1919)', offers a different perspective on the public significance of Christian faith in the post-Soviet space. Geychenko's deft engagement with the works of Ivanov offers a compelling critique of postSoviet evangelicals who advocate political or social non-involvement. Ivanov's life story and his understanding of the connection between the inward conversion of the individual believer and the outer public mission of the church provide a foundation for evangelical engagement that has much to teach postSoviet Christians today. What emerges from this article is a portrait of Ivanov as a pioneering figure, who in many ways was ahead of his time. Growing up among the non-conforming Molokan community, Ivanov perceived the ecclesial alternatives to the Orthodox hierarchy that were open to the Baptist church. By taking the Kingdom of God as his missional point of departure and emphasizing the role of the church in terms of witnessing to this Kingdom, Ivanov's writings seem to anticipate some of the key concepts that would later be expressed in Western theological thinking about the missio Dei. Geychenko develops his argument by bringing Ivanov's notion of a world-transforming theology into dialogue with a leading British Baptist (Paul S. Fiddes), and a prominent American Catholic (William T. Cavanaugh).

The important contribution that public theology makes towards the enhancement of Christian social engagement in Eastern Europe is a prominent theme in the article by Corneliu Constantineanu, entitled, 'Instruments of Justice: Biblical Contributions to a Public Theology of Engagement in Eastern European Context.' Drawing on key themes in the writings of the Apostle Paul, such as righteousness, justification and justice, Constantineanu explores how these ideas apply to public discourses on justice in the highly complex and problematic context of post-communist Eastern Europe. Challenging the alleged Western bias towards distributive and retributive forms of justice, Constantineanu advocates for a biblical understanding of justice that is holistic, relational and restorative in character. The public vocation of Christians finds expression in practices that are continuous with the biblical narrative of the life, death and resurrection of Jesus Christ. By living out the vocation to be 'instruments of justice', the people of God advance God's purpose for society to be established on a new footing of righteousness and justice. This vocation is simultaneously a summons to challenge and subvert the corruption and lawlessness that have blemished post-communist Eastern European society for many decades.

In the next article, 'Via Tertia for the Orthodox Churches', Cyril Hovorun makes a forceful case for the relevance of public theology in Ukraine following the Revolution of Dignity in 2013-14. Hovorun hails this landmark event as 
'a victory for civil society' over the state, which opened up to Ukraine a third way that circumvents the unenviable binary choice between either pursuing the nationalist agenda of nation-building or submitting to the yoke of Russian or Soviet neo-imperialism. The Russian military invasion of Ukraine that followed the Revolution forced the churches to confront the same choice between the nationalist agenda of modernity and Russian imperialism. Drawing on a theological lexicon of church engagement in civil society, Hovorun advocates a via tertia, a third way, focused on civil society, that avoids the perils of both unthinking nationalism and naïve acquiescence to Russian imperialism. This third way, contends Hovorun, leads to modernization of the state and society, but not according to the pattern of secularism and consumerism. This third way requires the churches neither to become co-ruler with the state, nor to withdraw from public life, but rather to infuse the social space with spiritual values of compassion, justice, forgiveness and solidarity. The third way is rooted in the 'theology of Maidan', which supplies the Ukrainian churches with a paradigm of public engagement. Drawing on recent events in Ukrainian politics and developments in church relations, Hovorun argues persuasively that such a model of Christian engagement with civil society helps to establish a proper coherence or 'symphony' between the church's witness in public sphere and the broader social and political developments in the country.

The volume concludes with a review article of Hovorun's recent pioneering book, Ukrainian Public Theology. The reviewer, Mykhailo Cherenkov, has emerged in recent years as a prominent and articulate voice advocating for a more active social and political engagement of post-Soviet Protestants. His critically sympathetic review of the work of Hovorun, a leading public theologian from the Orthodox confession, demonstrates the creative points of connection between Baptist and Orthodox approaches to public theology and the possibilities of ecumenical dialogue between traditional and free churches on issues of general public concern.

We hope that this volume will make a contribution towards the development of Christian engagement with the social and political challenges in this strategic region. Even now, thirty years after the demise of the USSR, Eastern Europe is still living in the shadow of Soviet Communism and its legacy of rampant corruption and dysfunctional models of relationship between church, state and civil society. The Soviet mentality of conformity and corruption and the deformation of social consciousness has far outlived the Soviet Union as a political entity. There are promising signs, however, that the recent crises in the spheres of politics, society and the church may herald the coming of a new epoch in the history of this region. Recent events in post-Soviet Eastern Europe have prompted original and creative thinking about the role of faith in 
the public sphere. One of the most important tasks of public theology in this region of the coming years will be to facilitate the emergence of civil society in order to consolidate democratic freedoms and embed Christian values of justice, compassion and solidarity in the public space. Most of all we hope that the articles will encourage others to explore new paths of inquiry in the emerging field of public theology.

\author{
Joshua T. Searle \\ Guest Editor \\ Director of Postgraduate Studies and Lecturer in Theology and Public \\ Thought, Spurgeon's College, London, United Kingdom \\ joshua@joshua-searle.com
}

